\title{
EASTERn PARTNERShIP VIS-À-VIS CHALlengeS AND DOUBTS
}

\author{
Partnerstwo Wschodnie wobec wyzwań i wątpliwości
}

\begin{abstract}
Eastern Partnership initiative and program sparkled ongoing and intensive debates. It raised some concerns and doubts regarding the efficacy and effectiveness of EaP. Still, the only country, which perceived this initiative of the EU as a direct threat was and is Russia. War against Georgia, later annexation of Crimea and War on Donbas, a hybrid war against Ukraine and many western countries are key challenges for the EU also. European Union and NATO are in a search for more consolidated respond towards new reality up today.

EaP design and potential are too weak to be good enough for partners' countries themselves. Despite many deficiencies, this policy is important to encourage horizontal cooperation of 6 partners' countries and make their ties with the EU stronger and more productive. However, the overall goals and instruments of EaP do require thorough reconsideration and new incentives to move forward from a current, somehow hesitant and stagnated, position.
\end{abstract}

Keywords: Eastern Partnership, challenges of security, Russia's Retro-imperialism

Abstrakt: Inicjatywa programu Partnerstwa Wschodniego wywołała wiele intensywnych dyskusji, które ciagna się do dziś. Przewijaja się w nich pewne obawy i watpliwości, dotyczace skuteczności i efektywności Partnerstwa Wschodniego. Niemniej jednak jedynym krajem, który przyjąt inicjatywę UE jako bezpośrednie zagrożenie, była i jest Rosja. Wojna z Gruzja, późniejsza aneksja Krymu i wojna w Donbasie, wojna hybrydowa z Ukraina i wieloma krajami zachodnimi, to wszystko stanowi kluczowe wyzwanie dla Unii Europejskiej. UE i NATO staraja sie wypracować bardziej skonsolidowana odpowiedź na tę nowa rzeczywistość.

Konstrukcja i potencjat Partnerstwa Wschodniego sa zbyt stabe, aby być propozycja na odpowiednim poziomie dla samych krajów partnerskich. Pomimo wielu niedociagnięć,

1 Prof. dr. hab. Anatoliy KRUGLASHOV, Research Institute of European Integration and Regional Studies, Chernivtsi Jury Fedkovych National University, e-mail: akruglas@gmail.com 
polityka Partnerstwa Wschodniego jest istotnym czynnikiem, pozytywnie wptywajacym na horyzontalna wspótprace między sześcioma krajami, oraz na zacieśnienie więzi z UE i uczynienie ich efektywniejszymi. Niemniej jednak ogólne cele i instrumenty programu Partnerstwa Wschodniego wymagaja gruntownego przemyślenia i wypracowania atrakcyjniejszej oferty dla państw stowarzyszonych, żeby możliwe było wyjście z obecnego stanu niezdecydowania i stagnacji.

Słowa kluczowe: Partnerstwo Wschodnie, zagrożenia bezpieczeństwa, retro-imperializm Rosji

\section{Introduction}

The first decade of EaP implementation happened to be overwhelmed with crises and new threats. Some of them seemed to be impossible after the end of the Cold war era. Poland and Sweden, advocating new Eastern European Policy of the EU, aimed at deepening European Neighborhood Policy (ENP), making it adopted towards peculiar needs and ambitions of countries of the region, as well as promoting their comprehensive and multilevel cooperation with United Europe. They hoped to overcome barriers and shortages of ENP and grant some post-soviet countries with advanced opportunities for fulfilling their European integration aspiration.

Most attractive and perspective incentives comprised a good chance of gradual economic integration for all six countries, enhancement of the political dialogue, and engagement of Civic society into furthering their ever closer cooperation with the EU. Association agreements and Dean and Comprehensive free trade area (DCFTA), together with a prospect of a visa-free regime, seemed to be much more solid foundations for a new policy, than a modest stimulus provided earlier with the outdated framework of Partnership and cooperation agreements.

After a decade of EaP implementation, one might observe some important and positive changes in motion. First of all, it concerns Georgia, Moldova, and Ukraine, which signed up and ratified the Association Agreement and moved to a realization of DCFTA. All of them are really profitable for those countries, making them more economically advanced and granting them certain access to the Single European market. Surely, this progress might be slowed down because of many problems experienced by the EU 
itself, and to a very extent, because of the remaining gap of all three states in economic standards, model and policies, elaborated with the EU. As far as so-called ordinary citizens' interests are concerned, the visa-free regime for them up to 90 days of stay in the EU have to be acknowledged as the beneficial move also. It directly or indirectly affects the lives of millions of people from Associated countries, enhancing their understanding of United Europe's foundation and function.

These short lists of EaP records are not final. However, looking for a more or less balanced evaluation of EaP for the countries engaged in particular, and the EU in general, one might face with too many contradictory opinions and remarks. One of the crucial points of EaP weakness is its security dimension. It affects the partner's countries first of all. Still, it poses a growing concern for the EU also, while countries from the former USSR and Soviet bloc first of all worry about their vulnerability and lack of certainty vis-à-vis Russia's reemerging aggressive and hegemonic pretense. Russia's regional and global has undergone radical and drastic changes for a recent decade. Maybe it mainly touched upon a set of tools and instruments, experimented on with Kremlin, while the principal goals of this policy seem to be set up much earlier by V. Putin. Whatever the explanation, it's obvious that the new turn of the Russian Federation policy met with unpreparedness of EaP countries, the EU, and western democracies by and large to coop with them duly and in a consolidated manner.

This article proposes a brief evaluation of EaP's main issues, Russia's reaction towards the program, and consideration of the Kremlin strategy in a region concerned.

\section{Hopes and disillusionment with EaP in action}

Historically, EaP emerged from the European Neighborhood Policy, initiated by Great Britain on the eve of the ever-greater Enlargement-2004. That initiative proposed to set down a brand-new model of relations with new neighbors of the enlarged EU. It was supposed to be more friendly, mutually beneficial, and rewarding for those who are ready to accept this offer from Brussels and move trustful relations forward into the circle of EU friends. Despite the pretty clearly determined concept of bilateral plans and distant perspective of economic 
integration, this move faced a lot of criticism and skepticism, both inside and outside of the EU.

From the very beginning, the ENP initiative has been flavored with a lack of proactive policy and looked suspiciously opportunistic. It combined with a prospect of building up new relations with European countries from Eastern Europe, which set down European integration as their strategic course, countries with neutral positioning towards the EU and states with rather a critical attitude to the EU and the west. Moreover, it did not differentiate the approaches to European and non-European countries of the new neighborhood. The basket of offers, made within ENP and ENPI, looked like a kind of political and economic hip-hops and left behind many countries unsatisfied and disappointed with actions to follow. These problems, being aggravated with the long-lasting effect of the EU wide-spread phobia of possible new Enlargements due to the high price of embracing new members from Eastern Europe, contributed to the syndrome of chronic 'tiredness' from the process of stretching the EU too far. It lied strict limitations on the ENP strategic horizons also.

The enlargement process, in turn, results in a few consequences and some complications for the EU's further development. Some of them occurred as a sort of collateral damages of the EU eastward, - and southward expansion. Of the most sensitive cases could be recalled a failure of European Constitution ratification in France and the Netherlands. It points out at considerable public distrust of the new stage of the European project and the political leadership associated with them. Lisbon Treaty has been somewhat easing tensions in the years to follow and helped to diminish key misbalances, affecting post-enlarged EU, but was not a solution to other problems required by the European Constitution's elaboration (Micklitz 2016: 109-140). Briefly, this is a context in which member-states discovered their different approaches to priorities and content of Neighborhood policy. For instance, Mediterranean countries. i.e. France, Italy, Spain, Greece, and for various reasons Germany looked primarily at the unstable situation in North Africa and Near East as the most dangerous source of political, military threats, concurrently illegal emigration and refugees' influx. They want resources of the EU to be targeted to the solution or easement of those regions' issues. Contrary to them, new members from Central and Eastern Europe were more concerned with the support of their eastern neighbors, a prospect of their European integration, especially because of emerging Russia's military and political threats. So, having accomplished 
adaptation to such a clash of confronting approaches and expectations regarding ENP and later complemented with ENPI, both 'camps' inside the EU had no other pragmatic choice as to find a certain compromise amidst each other. In doing so, they agreed finally with differentiation of Neighborhood policy into two principal directions, Mediterranean and Eastern European ones consecutively.

New Eastern European policy of the EU embodied into the EaP program and calculus behind them do not satisfy the desires and aspirations of all the parties concerned (Latoszek, Kłos 2016: 178). Member-states from CEE dreamt of much more attractive and inspiring stimulus for non-EU members. In fact, 6 countries of the partnership thought differently about the pros and cons the Program proposed for them. All the faults and failed expectations notwithstanding, EaP outlined more clear and concrete prospects for these 6 post-soviet states relations with the EU in comparison with Neighborhood policy provisions. It is a step forward which opens up new opportunities for the countries of the region (Арутюнян, Сергунин 2012: 90-97). Moreover, while undertaking EaP, the EU drafted, and put out a certain collective strategy for the specific region which previously did not get too much attention in the latter. Besides, it reasonably shifted its approach from the previous practice of individual negotiation with a chosen country in favor of proposing them a wider format of their cooperation both with the EU and themselves. All of these novelties have to have a promising output in the long run. Hereby, the EU became considering the specificity of the post-soviet region more carefully and broke up with its previous stance of looking and waiting for the currents of this turbulent and abstruse (from the western point of view) region.

It has been over ten years since the inauguration of this Program, and one should make a certain outline of gains and failures, characteristic to EaP. Let's start with gains, as there are certain achievements there (Дырина 2019). Firstly, it is worth noting the strengthening of trade and economic cooperation of EaP countries with the EU (Diacon 2019: 30-32). Secondly, and no less important is a certain intensification of political dialogue, which is grounded on more solid legal and institutional foundations. Surely, the results of them could be more considerable than they are. Thirdly, it brought about the activation of the European integration process in all of the three EaP countries, which proclaimed and kept up their strategic course to the EU membership, namely Georgia (Злобина 
2018: 170-187), Moldova (Мунтян, Мясников 2019: 7-9) and Ukraine. At the same time, while most visible results of EaP fulfilment are not typical for all of 6 partners' states, they might be attributed to associated countries mostly. The latter three have not reached the same records either (Артьомов 2019: 7-9). Mainly it means first fruits of Deep and Comprehensive Free-trade area, micro-financial aid, and support for making some sectoral reforms there (Vakieva 2016: 17-20). It comprises their involvement in the discussion of key issues of European and regional political agenda and, of course, people to people dimension of the cooperation.

Regarding Azerbaijan, Armenia, and Belarus, their balance of success and failure looks different. In the case of Azerbaijan, last decade hardly marked with breaking through outcome (Вишнякова 2018: 575-579). Officially, Baku has shown modest enthusiasm concerning EaP and relations with the EU, especially outside trade and economy issues. Less of all it demonstrates interest in democracy promotion and involvement of civic society through the Program. Armenia initially took part in negotiations on Association Agreement, but prior to the Vilnius summit of EaP dropped out of them. The leadership of the country prefers Custom Union and later Eurasian Union, led by Russia for some geopolitical and economic reasons. Dependency on Russia's energy and economic support had the deepest impact on Armenia's choice. Fear of Azerbaijan-Turkey alliance in the Nagorno-Karabakh crisis resolution has influenced this choice to a very large extend too (Камынин, Папоян 2019: 193-200).

Finally, Belarus - the closest ally of Russia, which is now under threat of incorporation by the latter, has the lowest position among EaP beneficiaries. There are lots of explanations for such a situation: the authoritarian regime in Minsk, the absence of PCA, the lack of trust from Brussels to Minsk, the one-sided orientation of president O. Lukashenko to Russia, etc. Time by time, Belarus tries to reopen dialogue with the EU. Usually, the honeymoon lasts for a short period, being used by the government in Minsk as a tool of demonstrating international actorness of the country and making Kremlin less tough regarding former claims and demands. As a result, Belarus takes a marginal part in EaP programs, enjoying cross-border cooperation, some migration control measures, ecological problem's resolution, etc. (Тихомиров 2018).

Admitting some positive changes in the Associated countries of EaP, their weaknesses and faults should be attended as well. First of all, these countries remain birds of the same flock because they are failed victims 
of separatists' movement and direct political threats and/or military aggression of Russia. Transnistrian crisis in Moldova, secessionists' wars in Abkhazia and South Ossetia, the annexation of Crimea and War at Donbas (Minakov 2019: 182-185), all of them begun with too many common features to ignore the main source of these tragedies. Besides, domestic policy in those newly independent states is remarkably burdened with many unresolved problems (Pachocka 2017: 17-31). Political stability and economic sustainability of these countries are under question, and democratic transformation is incomplete for various reasons from which dominant oligarchic trends are the key ones (Гетьманчук 2017). A hybrid democracy creates a gloomy picture there, which corresponds with the limits of civic society potential to extend control and make permanent pressure on the authorities, urging them with systemic reforms, and fight against corruption.

Overall, material and symbolic resources (Kruglashov 2016: 67-72), directed to partner countries by the EU, especially those striving for the fullfledged European integration, are not sufficient for their successful modernization. They aren't comparable with the aid which the EU allocated to candidate countries of CEE. What might be considered as a moral incentive from the EU to Eastern partners seems to be even less impressive, so far the official position of the EU and some member-states has often been pronounced. They reiterated too many times that for inspiring at future membership countries of EaP it is hardly accessible target at the foreseen future, and the EU does not plan any further enlargement except Western Balkan' countries (Нащочин 2019: 61-64). This stance of the EU evokes the deepest disappointment at Georgia, Moldova, and Ukraine, and paves a way towards anti-European manipulations and propaganda both inside and outside of those states. Strategically, this attitude is dangerous not only for Eastern Europe but for the future of the EU itself. For the EU's sake unclear position towards the countries of EaP, as well as to some other important European and global issues means negative consequences, up to the true generalization that the Union currently suffers from a loss of strategic orientation and attractiveness both internally and externally (Piskorska 2019: 33). 


\section{Russia's policy as a challenge and threat for EaP}

The EU initiative for the formation of the Eastern Partnership and its implementation causes numerous scientific and political discussions, and this is fully justified. However, the only country that perceived this policy as a direct challenge and a threat to its national interests was the Russian Federation (Арутюнян, Сергунин 2015). It should be noted that up to this point, the dialogue between the EU and the Russian Federation has been developing quite positively overall, covering a wide range of issues, and its parties considered and declared each other as strategic partners, building the logistics for achieving the long-term goals of their cooperation. Brussels had been emphasizing the priority of its relations with Russia till 2014, considering it not only one of the most important trade and economic partners but also a country which active engagement is necessary to solve security and development issues in the post-Soviet space and beyond.

If during the inauguration of the European neighborhood policy the EU answered the question about the role of Russia in its implementation, as Russia became such a neighbor with the EU enlargement in 1995, then the question of the reasons for the exclusion of the Russian Federation from the list of EaP countries looked less clear and convincing. Especially for the Kremlin establishment. The absence of such an answer was superimposed on the prevailing tendency in Moscow's intellectual and political circles to interpret global politics with the help of conspiracy theories and schemes of geopolitical "descriptive geometry." This, along with the tendency of the Russian Federation to position itself as a Eurasian leader, contributed to the fact that the Kremlin took the EaP as a direct challenge to its interests and ambitions (Сергунин 2010) from the "collective West", which is increasingly considered by the Russian Federation as a competitor and a threat to the Russian Federation.

Since 2008, the author of the article began to consider Russia's foreign and domestic policy precisely as retro-imperial and proposed the corresponding conceptual term. In our opinion, a practical turn from an attempt to pursue a neo-imperial policy (recall the idea of a "liberal empire" proposed by Chubais) to retro-imperialism took place precisely in the last years of the first decade of the 21st century.

At the same time, the ruling elite of the Russian Federation, while trying to legitimize the regime of consolidated authoritarianism in the country, began to "synthesize" the old imperial and great-power concepts (e.g. 
Moscow - the Third Rome, the Greek project, Panslavist concepts, Eurasians' and Neo-Eurasians schemes, etc.) mixing them up with a fear of 'colors revolutions' (Khan 2018: 35). Moreover, the stake was made on the glorification and heroization of the imperial past of Russia, depicting it as the true "Golden age" in the history of the country and state. A bloody path of imperial aggression, annexation, and centralization has been interpreted as a natural and organic historical way for Russia to move forward. The emphasis on an uncritical and increasingly mythological perception of former glory, the insistence on the "naturalness" of the imperial borders of Russia (modelled at 1914 frontiers?), a massive propaganda campaign designed to convince the population that "returning to roots" is right and leads to the salvation, all of these are only some parts of a new understanding and positioning of the Russian Federation, particularly in its foreign policy foundations.

Thus, from the Russian dominant point of view, both the eastward expansion of NATO and the beginning of the implementation of EaP represented an unacceptable encroachment on the "originally Russian" lands and interests. Moreover, during the previous period, since the time of the "Yeltsin-Kozyrev" doctrine, the so-called neighboring countries were presented by the Kremlin and tacitly perceived by Western partners as a sphere of so-called special national interests of the Russian Federation. Thus, EaP was understood in the Kremlin both as an encroachment on these interests, and as evidence that the "West" does not respect and does not adhere to previously reached "gentlemen's agreements".

This retro-imperial policy of the Kremlin begins to move from the preparatory stage of its conceptualization, mediation, and massive propaganda into a practical area starting in 2008, and becoming more and more aggressive later on (Trenin 2016: 23). At the same time, the author believes that the EaP was not the reason, but one of the catalysts for this transition to the new phase of the Russian foreign policy, yet another of its triggers.

The first large-scale demonstration of the Kremlin's determination to use military force is the war with Georgia in August 2008, when Russian armed forces "miraculously" turned from peacekeepers into defenders of the inhabitants of South Ossetia (whom Russia previously turned massively into its citizens). The response to these actions from the EU was slurred and mostly confused. It seems that the leaders of the Western countries did not make timely conclusions from this situation. Without denying M. Saakashvili's share of responsibility for what happened, let 
us express the opinion that he clearly sought to repeat V. Putin's scenario of the "second Chechen war" in South Ossetia. But, as it became obvious, such political plagiarism in the Kremlin was not accepted with a possible understanding.

Power methods to solve the problems of the Kremlin's retro-imperial policy, not facing the necessary opposition, showed themselves on a large scale during the annexation of Crimea, starting in February 2014. Despite the obvious lie about the "green men" in Crimea from Russian politicians and the media during the deployment of this operation, after it turned out successfully, the president of Russia publicly acknowledged that this operation was prepared by the Russian Federation for more than 10 years prior to its open phase. The Crimean special operation, among other things, was called upon to demonstrate the readiness of the current owner of the Kremlin to Russians and the world, not with words, but with actions "to collect Russian lands". Poorly disguised as the creation of the so-called "DPR" and "LPR", the subsequent occupation of Donbas' parts poses a direct challenge not only to Ukraine and the countries of the East European region (Russu 2018: 65) but also to the entire pan-European security system. At the same time, the scale of the hybrid war unleashed by the Russian Federation and continuing up to this day is not limited either to the territory of Ukraine or the post-Soviet space, even to European territory (Lanoszka 2016: 175-195). Many EU countries and the USA, for example, are its target. One must pay tribute to the Kremlin authors of the new strategy of "confronting the West" in that they carefully take into account and exploit any vulnerabilities of their opponents and competitors, whether in the social, political, or information sphere. And so far, they have not saved resources for these purposes. All this raises the question of the readiness of the EU and NATO to repel such threats and new challenges. Despite some economic, informational, and political response actions (Oliker, Michael, Lynn 2015), a more powerful and convincing reaction is still expected from them.

\section{Conclusions}

While evaluating the process of EaP launch and development, one could admit that important positive results have been reached. Mostly, 
the level and quality of some advancements of the three states associated with the EU, Georgia, Moldova, and Ukraine, respectively. Still, from their standpoint, these outcomes do not correspond with their European aspirations and goals, and they are not sufficient as far as their security and socio-economic interests are concerned. From their part, these countries are too slow and sometimes inaccurate with duly implementation of some obligations they undertook. The lion share of responsibility for those inconsistencies should be addressed to their political leadership and the political class as a whole. Partly, domestic problems of the three countries are rooted in their social and cultural specificity, inherited from the previous system. Namely, infantilism and too high paternalistic expectations. They opened up the Pandora box for manipulations with public opinion in the associated countries and made themselves susceptible to destructive influences of domestic and foreign actors. Together with recurrent political instability, and dominant poverty, these factors are damaging to the countries' democratic prospects and sustainable economic growth.

Another part of the responsibility for current failures and dramatic events could be addressed to the leadership of some EU member-states and Brussels. Taking into account not-stop series of crises affecting United Europe since 2008 (financial crises (Asteriou, Konstantinos 2019: 238-245), migrant afflux or refugee crisis (Panebianco, Iole 2018: 1-17), the crisis in Ukraine and Brexit (Oehler, Horn, Wendt 2017: 175-181), it's no wonder that all of them impede and undermine the very ability of the EU to properly support Eastern partnership program. However, the support and attention paid to partners' states from the EU institutions should be more considerable and all-comprehensive. It concerns aspirant countries, aiming at successful European integration as well as non-aspirant countries, which formulated a self-limited agenda of their cooperation with the EU. That's why EaP needs careful revision and correction up to the current circumstances and future perspective (Сидорук 2018: 138-151).

First and foremost, countries striving to European integration have to be differentiated into a distinct group from those states which do not pursue such a goal. A policy of conditionality should be applied to Georgia, Moldova, and Ukraine with a clear perspective of their gradual but steady integration with the EU. As the principal new stage of their approximation to the EU, they have to get candidate states status in the forthcoming years. 
Secondly, it is vital for all of the EaP states to participate in the vivid horizontal cooperation within the region, centered at key issues resolutions. Another priority to be realized is the encouragement of this cooperation and the promotion of its values by Brussels. For instance, support for the activity of civic society institutes, the inclusion of citizens in the decision-making process, the entitlement of NGOs to partake in public control upon all levels of authorities, etc. The aforementioned examples are in no way panacea, but they can be effective remedies for some chronic diseases of post-soviet countries.

Thirdly, it seems that dominant neglect of regional security factors and their dynamics was EaP's conceptual error at the beginning. An example of this is the misunderstanding of a possible Russia's role in new Program implementation. If there was any prognosis, they hardly took into proper consideration possible Kremlin reactions and did not make reasonable risk-management precautions. As it is clear for now, security reasons are at the forefront of partners' countries struggle for survival and further development. They require finding an instant solution for that concern, and mainly in the context of Russian retro-imperial policy counteraction.

Finally, the shape and content of EaP remain weak and nonsufficient as a framework and vehicle of its participant problem resolution. It does not mean that the situation in the region and Europe would have been better without this program, hardly so. It means that the Eastern European policy of the EU and its member-states should have to be reconsidered and re-activated. In doing so, the EU and partners' states have to move forward toward more active cooperation. For some countries, it implies a realistic prospect of integration with United Europe.

\section{References}

Asteriou, D. and S. Konstantinos (2019), 'The relationship between financial development and economic growth during the recent crisis: Evidence from the EU', Finance Research Letters, 28: 238-245.

Diacon, M. (2019), 'Eastern partnership: 10 years of cooperation, development and integration', Dialog intercultural pol ono-moldovenesc, 3:30-32.

Khan, H. (2018), 'EU'S Eastern Partnership and the Russian Near Abroad: a contested arena', Journal of European Studies, 34(2): 35. 
Kruglashov, A. (2016), 'Ukraine in the framework of the Eastern partnership: lessons still to be learnt about', in EU Relations with Eastern Partnership: Strategy, Opportunities and Challenges, (Chisinau-Chernivtsi-Tbilisip): 67- 72.

Lanoszka, A. (2016), 'Russian hybrid warfare and extended deterrence in eastern Europe', International Affairs, 92 (1):175-195.

Latoszek, E. and A. Kłos (2016), 'The Eastern partnership as a new form of the European Union's cooperation with the third countries', Studia z Polityki Publicznej, 11(3): 178.

Micklitz, H.-W. (2016), 'Failures or Ideological Preconceptions? Thoughts on Two Grand Projects: The European Constitution and the European Civil Code', in S. Sankari (eds), The Many Constitutions of Europe (London: Routledge): 109-140.

Minakov, M. (2019), 'Post-soviet Eastern Europe. Achievements in post-soviet development in six Eastern European nations', 1991-2020', Ideology and Politics, 14(3):182-185.

Oehler, A., M. Horn, and S. Wendt S. (2017), 'Brexit: Short-term stock price effects and the impact of firm-level internationalization', Finance Research Letters, 22:175-181.

Oliker, O., J. Michael and E. Lynn (2015), NATO needs a comprehensive strategy for Russia, Rand National Defense Research Institute, Santa Monica CA, 21, https:/ / apps.dtic.mil/dtic/tr/fulltext/u2/a616004.pdf (12.12.2019).

Pachocka, M. (2017), 'The Eastern Partnership in Times of the Migrant and Refugee Crisis in the European Union', Eurolime, 22:17-31.

Panebianco, S. and F. Iole (2018), 'When responsibility to protect 'hits home': the refugee crisis and the EU response', Third World Quarterly, 39 (1):1-17.

Piskorska, B. (2019), 'Is the European Union still an attractive international actor? Challenges for the global role of the EU', Przegląd Europejski, 3: 33.

Russu, R. (2018), 'Threats and challenges for young European countries in new international conditions, using Ukraine and Moldova as a case study', Iсторикополітичні проблеми сучасного світу, 37-38: 65.

Trenin, D. (2016), 'The revival of the Russian military', Foreign Affairs, 5(3): 23.

Vakieva, K. (2016), 'The EU's Eastern Partnership: normative or geopolitical power projection', Eastern Journal of European Studies, 7(2):17-20.

Артьомов, I. (2019), 'Десятиліття Східного Партнерства: проблеми і перспективи', Геополітика України: історія і сучасність, 22(1): 7-9.

Арутюнян О. и А. Сергунин (2015), 'Между Сциллой и Харибдой: программа «Восточного партнерства» на перекрестье геополитических интересов Евросоюза и России', Вестник СПбГУ. Серия 6. Политология. Международные отношения, 2, https://cyberleninka.ru/article/n/ mezhdu-stsilloy-i-haribdoy-programma-vostochnogo-partnerstva-naperekrestie-geopoliticheskih-interesov-evrosoyuza-i-rossii (01.12.2019). 
Арутюнян, О. и А. Сергунин (2012), 'Восточное партнерство ЕС: второе дыхание', Научно-аналитический журнал Обозреватель, 1(264): 90-97.

Вишнякова, А. (2018), 'Страны южного Кавказа: между Восточным партнерством Европейского Союза и Россией как центрами интеграционного притяжения', Аллея науки, 4(3):575-579.

Гетьманчук, А. (2017), ‘3 «історії успіху» - в «олігархічну диктатуру» Які уроки Україні варто взяти у Молдови', Дзеркало тижня, 43.

Дырина, А. (2019), 'Восточное партнерство. Настоящее и будущее программы', Европейская безопасность: события, оценки, прогнозы, 53(69), https:/ / cyberleninka.ru/article/n/vostochnoe-partnerstvo-nastoyaschee-ibuduschee-programmy (01.12.2019).

Злобина, Е. (2018), Сотрудничество Грузии и ЕС в рамках Европейской политики соседства и Восточного партнерства, 2004-2017 гг., (Томск: Европа и Европейский Союз глазами ученых): 170-187.

Камынин, В. и А. Папоян (2019), 'Особенности отношений Республики Армения и Европейского союза', Известия Уральского федерального университета, Сер. 3, Общественные науки, 191(3):193-200.

Мунтян, К. и Н. Мясников (2019), 'Республика Молдова в контексте Восточного измерения европейской политики', в Инновационные технологии в науке и образовании, 366-369.

Нащочин, О. (2019), 'Східне партнерство або інтеграція без членства', Гілея: науковий вісник. Випуск, 143(3):61-64.

Сергунин А. (2010), 'Восточное партнерство»: вызов российской дипломатии в Восточной Европе', Вестник ВГУ. Серия: Лингвистика и межкультурная коммуникация, 1, https://cyberleninka.ru/article/n/vostochnoepartnerstvo-vyzov-rossiyskoy-diplomatii-v-vostochnoy-evrope (01.12.2019).

Сидорук, Т. (2018), 'Десять років східному партнерству: час для перегляда', Політичне життя, 1:138-151.

Тихомиров, А. (2018), 'Восточное партнерство и его значение для Беларуси', Журнал международного права и международных отношений, 3-4, - http:/ / elib.bsu.by/handle/123456789/219676 (12.12.2019). 